\title{
Therapeutic Potential of Brazilian Fluoride Varnishes: An In Vivo Study
}

\author{
Marcella Quirino de ALMEIDA ${ }^{1}$ \\ Olívia Ximenes Izidro COSTA ${ }^{1}$ \\ Jainara Maria Soares FERREIRA ${ }^{2}$ \\ Valdenice Aparecida de MENEZES ${ }^{1,2}$ \\ Rossana Barbosa LEAL ${ }^{1}$ \\ Fábio Correia SAMPAIO ${ }^{3}$ \\ ${ }^{1}$ Caruaru Associação of Graduate Education, Caruaru, PE, Brazil \\ ${ }^{2}$ Dental School, University of Pernambuco, Camaragibe, PE, Brazil \\ ${ }^{3}$ Department of Clinic and Community Dentistry, Federal University of Paraíba, João Pessoa, PB, Brazil
}

\begin{abstract}
The aim of this study was to assess in vivo the therapeutic effect of three fluoride varnishes available in the Brazilian market on the performance of white spot lesions (WSL). The sample included 36 children aged 7 to 13 years old, with a total of 67 active WSL in permanent anterior teeth. The children were randomly divided into 3 groups, according to fluoride varnish used: FL- Fluorniz ( $\mathrm{n}=24)$, DUO - Duofluorid XII ( $\mathrm{n}=22)$ and DF - Durafluor $(\mathrm{n}=21)$. Maximum WSL dimensions (mesiodistal and incisogingival) were measured in millimeters by a previously calibrated single examiner using a periodontal probe. WSL were also assessed regarding lesion activity. Initial and final S-OHI (Simplified Oral Hygiene Index) scores were recorded. Pearson's chi-square test revealed no statistically significant differences $(p>0.05)$ in the performance of the varnishes. At the end of the 5th week, FL had 6 active and 18 inactive WSL; DUO had 7 active and 15 inactive WSL; and DL had 6 active and 15 inactive WSL. Taking into account all lesions, there was a 45.7\% reduction in WSL dimensions. Paired Student's t-test revealed a statistically significant difference $(\mathrm{p}<0.05)$ between the initial size (1.88) and final size (1.02). After four applications, all varnishes obtained similar clinical results.
\end{abstract}

Key Words: white spot lesion, tooth remineralization, topical fluoride, fluoride varnish.

\section{INTRODUCTION}

Dental caries is a multifactorial disease defined as a result of loss of mineral leading to dissolution of dental hard tissues by substantial $\mathrm{pH}$ fluctuations within the biofilm on the tooth surface (1-3).

White spot lesions (WSL) are the first visual clinical presentation of dental caries and are characterized by demineralization of the subsurface of the enamel, with increase in porosity due to the removal of minerals from the deep tissue to the external surface, may be either active (rough and opaque) or inactive (smooth and shiny) (4).

Fluorides play a significant role in the remineralization process (5). The constant presence of fluoride in the oral cavity through the use of topical methods occurs due to the formation of calcium fluoride
$\left(\mathrm{CaF}_{2}\right)$ on the enamel surface, acting as a reservoir of $\mathrm{pH}$-controlled fluoride ions $(5,6)$. The most common forms of the topical application of fluorides are dentifrices, mouthwash solutions, gels and varnishes (7). Fluoride varnishes have gained popularity due to their high concentration and safety during application (8). A number of studies have demonstrated that fluoride varnishes are able to remineralize incipient carious lesions as well as prevent decay when used with other preventive measures, such as diet control and reduction of dental biofilm (9-12).

Considering the small number of clinical studies evaluating Brazilian fluoride varnishes, the aim of the present study was to investigate the therapeutic effect of these products on the remineralization of active WSL in schoolchildren attending a daycare center in the city of Caruaru, PE, Brazil. 


\section{MATERIAL AND METHODS}

The study was approved by the Research Ethics Committee of the Caruaru Association of Graduate Education, Brazil (Protocol number 070/09).

Seventy-eight male and female children aged 7 to 13 years attending the 'Lar da Criança Nossa Senhora do Carmo' daycare center in Caruaru city were examined. Thirty-six children with incipient active carious lesions (rough, opaque WSL) in permanent anterior teeth were randomly selected for the present study. Parents/ guardians signed an informed consent form authorizing participation of the children.

Clinical examination and application of the fluoride varnishes were carried out at the daycare center under natural light in an open environment. A form was drafted for the identification of the child and recording of the data. Data were collected by a single calibrated researcher, reaching $\mathrm{k}=0.72$ for activity and $\mathrm{k}=0.60$ for diameter, which are considered as substantial and moderate coefficients, respectively (13). Clinical examination involved the use of the simplified Oral Hygiene Index (S-OHI) (14) and WSL dimensional alterations, texture and brightness (15).

$\mathrm{S}-\mathrm{OHI}$ was scored at the beginning and end of the study by a basic fucsin solution (Eviplac Solução; Biodinâmica, Ibiporã, PR, Brazil) used on the buccal faces of the permanent maxillary first molars and right central incisor, and on the lingual faces of the permanent mandibular first molars and left central incisor. Dental biofilm was scored as follows: $0=$ biofilm-free surface; 1 $=1 / 3$ of surface covered with biofilm; $2=2 / 3$ of surface covered with biofilm; $3=$ all surface covered with biofilm.

Supervised toothbrushing was carried out prior to the application of the fluoride varnishes in all sessions and after S-OHI. Each child received a children's toothbrush (Colgate Classic Infantil; Colgate-Palmolive, São Bernardo do Campo, SP, Brazil) and dentifrice containing 1,500 ppm of fluoride (Colgate-Palmolive). Standardized instructions were given in order to ensure the same oral hygiene conditions for all the participants.

Maximum lesion dimension was measured with a WHO periodontal probe (Trinity, Jaraguá do Sul, SP, Brazil). The values of WSL dimension represented the mean of the largest mesiodistal (horizontal) and incisogingival (vertical) diameters in millimeters. Incipient carious lesions were assessed by dimensional changes and clinical features of texture (roughness or smoothness) and brightness (opacity or shine) to be classified as either active (rough and opaque WSL) or inactive (smooth and shiny WSL), as previously described (15).

The children were randomly divided into 3 groups, each with 12 children using different fluoride varnishes: FL $(\mathrm{n}=24)$ - Fluorniz ( $5 \% \mathrm{NaF}$, SS White, Rio de Janeiro, RJ, Brazil); DUO ( $\mathrm{n}=22)$ - Duofluorid XII (6\% $\mathrm{CaF}_{2}+6 \% \mathrm{NaF}$, FGM, Joinville, SC, Brazil); and DF ( $\mathrm{n}=21)$ - Durafluor (5.5\% NaF, Dentsply Ind. e Com. Ltda., Petrópolis, RJ, Brazil).

The clinical procedures consisted of the following steps: 1) supervised toothbrushing; 2) relative isolation using cotton rolls; 3) drying with gauze; 4) application of fluoride varnish on active WSL with a microbrush (FGM); 5) 5-min wait for the evaporation of the solvent; 6) removal of cotton rolls; 7) recommendations (the children was instructed not to brush their teeth and consume only liquids or pasty foods in the $12 \mathrm{~h}$ following the application of the product). These clinical procedures were carried out once a week during 4 consecutive weeks. On the 5th week, the carious lesions were reevaluated (16) with regard to texture, luminosity and activity.

Pearson's chi-square text, Pearson's exact test, Student's t-test and ANOVA followed by Tukey's test were used for the analysis of the results. The Statistical Package for the Social Sciences (SPSS; SPSS Inc., Chicago, IL, USA), version 17.0, was used for all statistical analyses with 5\% significance level.

\section{RESULTS}

Thirty-six children participated in the study [27 boys (75\%) and 9 girls $(25 \%)$, with a mean \pm SD age of $9.83 \pm 1.48$ years]. The sample was comprised by 67 WSL located on the buccal surface of permanent anterior teeth. As described in the inclusion criteria, all incipient carious lesions had clinical characteristics of active (rough and opaque) at the beginning of the study. There was a statistically significant difference in S-OHI scores (Fig. 1) between the initial $(1.96 \pm 0.60)$ and final $(0.88 \pm 0.44)$ evaluation, thereby demonstrating an improvement in oral hygiene conditions $(\mathrm{p}<0.05$, paired Student's t-test).

Regarding the activity of the WSL submitted to treatment with fluoride varnishes, FL had $6(25 \%)$ active and 18 (75\%) inactive WSL; DUO had 7 (31.8\%) active and 15 (68.2\%) inactive WSL; and DF has 6 (28.6\%) active and $15(71.4 \%)$ inactive WSL on the final evaluation ( $p>0.05$; Pearson's chi-square test), as 
demonstrated in Table 1.

Among the 67 initial lesions, 19 (28.4\%) remained active and 48 (71\%) became inactive at the end of the study. There was a $45.7 \%$ reduction in the dimension of the WSL. The paired Student's t-test revealed a statistically significant difference $(\mathrm{p}<0.05)$ between the initial size $(1.88 \pm 0.68)$ and final size $(1.02 \pm 0.79)$.

Figure 2 shows the mean and standard deviation for WSL dimensions in millimeters at the initial and final evaluations, which were respectively $1.75 \pm 0.72$ and $0.97 \pm 0.80$ in FL; $1.98 \pm 0.72$ and $1.08 \pm 0.74$ in DUO; and $1.91 \pm 0.60$ and $1.01 \pm 0.86$ in DF. There were no

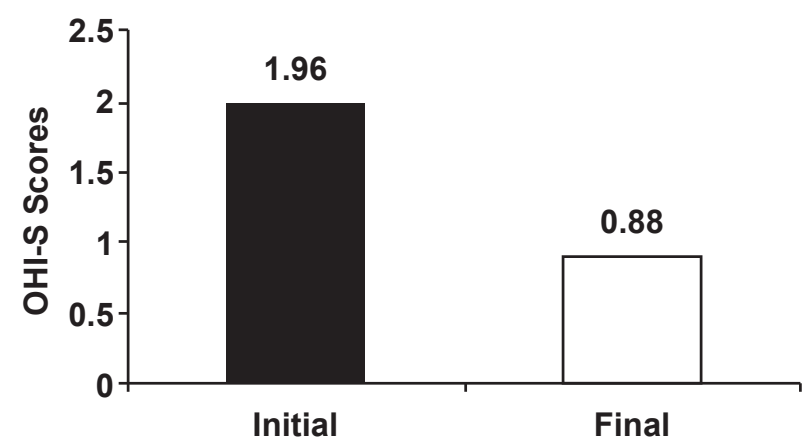

Figure 1. Distribution of mean OHI-S scores on initial and final evaluations. statistically significant differences between the fluoride varnishes tested ( $>0.05$, ANOVA and Tukey's test). However, each fluoride varnish achieved a significant reduction in mean WSL dimension when compared to the initial values $(\mathrm{p}<0.05$, paired Student's t-test).

\section{DISCUSSION}

Evidence-based clinical recommendations are developed through the evaluation of the collective evidence on a particular topic to provide practical applications of scientific information that can assist

Table 1. Clinical evaluation of the activity of white spot lesions subjected to treatment with the fluoride varnishes.

\begin{tabular}{lccc}
\hline & \multicolumn{2}{c}{ Activity } & Total \\
\cline { 2 - 3 } Groups & Active & Inactive & \\
& $\mathrm{n}(\%)$ & $\mathrm{n}(\%)$ & $\mathrm{N}(\%)$ \\
\hline FL & $6(25)$ & $18(75)$ & $24(100.0)$ \\
DUO & $7(31.8)$ & $15(68.2)$ & $22(100.0)$ \\
DF & $6(28.6)$ & $15(71.4)$ & $21(100.0)$ \\
Total & $19(28.4)$ & $48(71.6)$ & $67(100.0)$ \\
\hline
\end{tabular}

( $>>0.05$, Pearson's chi-square test).

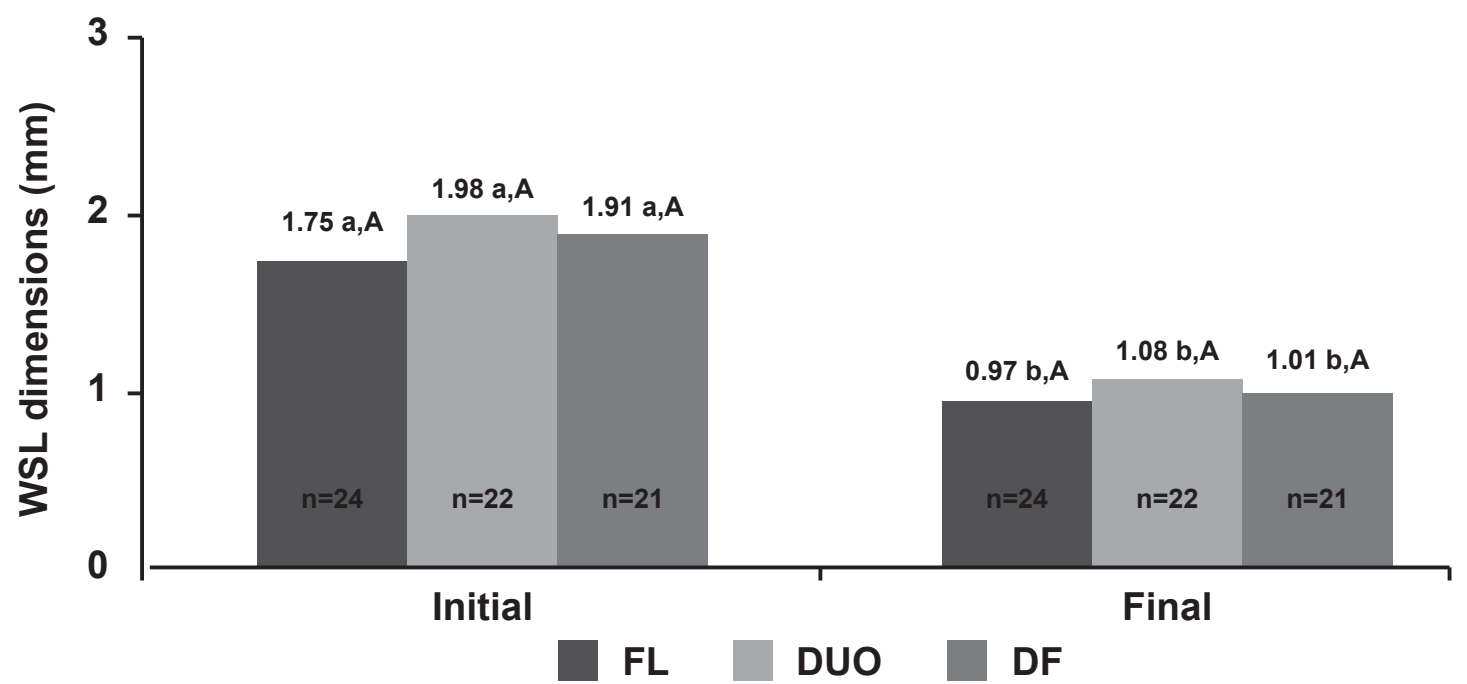

Figure 2. Distribution of mean dimensions of the white spot lesions (in $\mathrm{mm}$ ) according to the fluoride varnish used at baseline and at the end of the 5th week. *Means followed by different lowercase letters indicate statistically significant difference between initial and final evaluations ( $p<0.05$, paired Student's t test). Means followed by uppercase letters indicate non-significant difference between groups on the same evaluation ( $\mathrm{p}>0.05$, ANOVA and Tukey's test). 
dentists in clinical decisions (7).

Regarding the oral hygiene of the participants in the present study, a significant improvement on the $\mathrm{S}-\mathrm{OHI}$ occurred between the beginning (regular) and end of treatment (good). According to Ferreira et al. (15), the remineralization of WSL using a fluoride varnish may aid the action of fluoride dentifrices used for oral hygiene in patients submitted to fluoride treatment. Thus, in the present study, the beneficial association of fluoride and hygiene in reducing WSL cannot be disregarded, as the success of fluoride therapy depends on the motivation of the children to improve oral hygiene.

Four sessions of the fluoride varnish were carried out in the present study. Ferreira et al. (16) submitted incipient active carious lesions to treatment with different fluoride products for 4 weeks and found a reduction or a arrestment of the majority of the WSL.

All the fluoride varnishes tested in this study were effective in reducing active incipient caries lesions, with no significant differences between them. One possible explanation for this outcome can be explained by the high content of fluoride in the 3 tested products. In addition, there was a relative narrow difference in the range of fluoride concentration $(0.5-1.0 \%)$ in the tested varnishes. The additional benefit of incorporating $\mathrm{CaF}_{2}$ in one of the products was not observed in this study. However, taking into account our study design it is not possible to conclude that any beneficial gain did not take place. Additional measurements, such as calcium biding sites, may be necessary to investigate the possible additional effects of incorporating calcium in a varnish formulation. Future studies must consider the monitoring of calcium and fluoride as a variable to be explored for clarification of this issue.

The occurrence of inactive lesions (smooth and shiny) after the 4th varnish application demonstrates the possibility of paralyzing WSL without the need for an invasive treatment. This finding corroborates those of previous studies $(6,10,12,16,18,19)$. There was a $45.7 \%$ reduction in WSL size, which is in agreement with previous studies $(9,10,12,16)$.

There was no significant difference between the fluoride varnishes tested and each product obtained a significant reduction in the mean diameter of the lesions. Similar results were found in the in vivo and in vitro study carried out by Slade et al. (20), comparing Fluorniz, Durafluor and Duofluorid was well as in the in vivo study carried out by Ferreira et al. (16), who assessed Duraphat and Duofluorid XII fluoride varnishes.
Based on the findings of the present study, it may be concluded that the Brazilian fluoride varnishes evaluated were effective in reducing or arresting the WSL. These aspects can be relevant for dental public health services when planning oral health care programs especially in children.

\section{RESUMO}

O propósito do presente estudo foi avaliar in vivo o efeito terapêutico de 3 vernizes fluoretados disponíveis no mercado brasileiro em lesões de mancha branca (MB). A amostra foi composta de 36 crianças entre 7 e 13 anos, portadoras de 67 $\mathrm{MB}$ ativas em elementos dentários permanentes anteriores. As crianças foram divididas aleatoriamente em 3 grupos FL - Fluorniz $(n=24)$, DUO - Duofluorid XII $(n=22)$ e DF - Durafluor $(n=21)$. A dimensão máxima da $\mathrm{MB}$ (mésio-distal e cérvico-incisal) foi mensurada em milímetros por um único examinador previamente calibrado através de uma sonda periodontal. Em adição, foi verificada a atividade da MB. O IHO-S (Índice de Higiene Oral Simplificado) inicial e final foi registrado. O teste do qui-quadrado de Pearson mostrou não existir diferença estatisticamente significante $(\mathrm{p}>0,05)$ no comportamento dos vernizes estudados. No final da $5^{\mathrm{a}}$ semana o FL apresentava $6 \mathrm{MB}$ ativas e 18 inativas, DUO 7 MB ativas e 15 inativas e DF $6 \mathrm{MB}$ ativas e 15 inativas. Levando em consideração o grupo total, houve uma redução de $45,7 \%$ da dimensão das manchas brancas. O teste T pareado revelou uma diferença estatisticamente significante $(\mathrm{p}<0,05)$ entre o tamanho inicial $(1,88)$ e final $(1,02)$. Após 4 aplicações, todos os vernizes apresentaram resultados clínicos semelhantes.

\section{ACKNOWLEDGEMENTS}

The authors are grateful to SS White for the donation of the Fluorniz fluoride varnish and funding.

\section{REFERENCES}

1. Fejerskov O. Changing paradigms in concepts on dental caries: consequences for oral health care. Caries Res 2004;8:182-191.

2. Kidd EAM, Fejerskov O. What constitutes dental caries? Histopathology of carious enamel and dentin related to the action of cariogenic biofilms. J Dent Res 2004;83:C35-C38.

3. Moura LFAD, Moura MS, Toledo AO. Dental caries in children that participated in a dental program providing mother and child care. J Appl Oral Sci 2006;14:53-60.

4. Zero DT. Dental caries process. Dent Clin North Amer 1999;43:635-663.

5. ten Cate JM. Review on fluoride with special emphasis on calcium fluoride mechanisms in caries prevention. Eur J Oral Sci 1997; 105:461-465.

6. Ögaard B. Effects of fluoride on caries development and progression in vivo. J Dent Res 1990;69:813-819.

7. American Dental Association Council on Scientific Affairs: Professionally applied topical fluoride. Evidence-based clinical recommendations. J Am Dent Soc 2006;137:1151-1159.

8. Blinkhorn A, Davies R. Using fluoride varnish in the practice. $\mathrm{Br}$ Dent J 1998;185:1247-1253. 
9. Du M, Cheng N, Tai B, Jiang H, Li J, Bian Z. Randomized controlled trial on fluoride varnish application for treatment of white spot lesion after fixed orthodontic treatment. Clin Oral Investig 2011 [Epub ahead of print. DOI: 10.1007/s00784-0110520-4].

10. Seppä L. Studies of fluoride varnishes in Finland. Proc Finn Dent Soc Helsinki 1991;87:541-547.

11. Slade GD, Bailie RS, Roberts-Thomson K, Leach AJ, Raye I, Endean C, et al.. Effect of health promotion and fluoride varnish on dental caries among Australian Aboriginal children: results from a community-randomized controlled trial. Community Dent Oral Epidemiol 2011;39:29-43.

12. Weintraub JA, Ramos-Gomez F, Jue B, Shain S, Hoover CI, Featherstone JD, et al.. Fluoride varnish efficacy in preventing early childhood caries. J Dent Res 2006;85:172-176.

13. Bulman JS, Osborn JF. Measuring diagnostic consistency. Br Dent J 1989;166:377-381

14. Greene JC, Vermillion JR. The simplified oral hygiene index. J Am Dent Assoc 1964;68:25-31.

15. Ferreira JMS, Silva MF, Oliveira AF, Sampaio FC. Evaluation of different methods for monitoring incipient carious lesions in smooth surfaces under fluoride varnish therapy. Int J Paediatr Dent 2008; 18:300-305.
16. Ferreira JMS, Aragão AKR, Rosa ADB, Sampaio FC, Menezes VA. Therapeutic effect of two fluoride varnishes on white spot lesions: a randomized clinical trial. Braz Oral Res 2009;23:446451.

17. Shekelle PG, Woolf SH, Eccles M, Grimshaw J. Developing clinical guidelines. West J Med 1999;170:348-351.

18. Khattak MF, Conry JP, Ko CC. Comparison of three topical fluorides using computer imaging. J Clin Pediatr Dent 2005;30:139-144.

19. Ekstrand KR, Bakhshandeh A, Martignon S. Treatment of proximal superficial caries lesions on primary molar teeth with resin infiltration and fluoride varnish versus fluoride varnish only: efficacy after 1 year. Caries Res 2010;44:41-46.

20. Santos LM, Reis JIL, Medeiros MP, Ramos SM, Araújo JM. In vitro evaluation of fluoride products in the development of carious lesions in deciduous teeth. Braz Oral Res 2009;23:296-301.

Accepted March 15, 2011 